\title{
DRUG INTERACTION BETWEEN IVERMECTIN AND ETOMIDATE: INVESTIGATION ON THE EFFECT OF IVERMECTIN ON ETOMIDATE ANAESTHESIA
}

\author{
UFUK MERCAN YÜCEL $^{1 *}$, AHMET CIHAT ÖNER ${ }^{1}$, IDRRIS TÜREL ${ }^{2}$, ORHAN YILMAZ $^{3}$ \\ ${ }^{1}$ Van Yüzüncü Yll University, Veterinary Faculty Pharmacology and Toxicology Department, Turkey \\ ${ }^{2}$ Bolu Abant Izzet Baysal University, Medicine Faculty, Medical Pharmacology Department, Turkey \\ ${ }^{3}$ Van Yüzüncü Yll University, Pharmacy Faculty, Basic Science Department, Turkey \\ *corresponding author: umercan@yyu.edu.tr
}

Manuscript received: January 2020

\begin{abstract}
The present study aims to determine the effect of ivermectin on the duration of anaesthesia performed with etomidate and to find out if there are any interactions between these two drugs at the central nervous system level. For this purpose, 25 Sprague-Dawley female rats were divided into 5 groups with 5 rats in each group. Group I received only subcutaneous saline at a dosage of $0.1 \mathrm{ml} / 100 \mathrm{~g}$ bw. Group II received the intraperitoneal injection of propylene glycol at a dosage of $1 \mathrm{~mL} / 100 \mathrm{~g}$ bw. Group III received the subcutaneously $0.2 \mathrm{mg} / \mathrm{kg}$ bw ivermectin. Two hours after these treatments, neuropharmacological tests (rotarod and open field) were performed. Also, Group IV received $20 \mathrm{mg} / \mathrm{kg}$ bw etomidate intraperitoneally. Group V received subcutaneously $0.2 \mathrm{mg} / \mathrm{kg}$ bw ivermectin and 2 hours after the ivermectin administration, $20 \mathrm{mg} / \mathrm{kg}$ bw etomidate was given intraperitoneally. In these two groups, anaesthesia was monitored and the sleep duration was calculated based on rectal reflexes. Once the animals were fully awake, neuropharmacological tests were performed. Ivermectin that was administered two hours before the etomidate anaesthesia prolonged etomidate sleeping duration strongly. Also, ivermectin increased motion and decreased motor coordination, in association with etomidate it potentiates CNS depression (with prolonged sleep duration and decreased motor coordination).
\end{abstract}

\section{Rezumat}

Studiul îşi propune să evalueze efectul ivermectinei asupra duratei anesteziei cu etomidat și să stabilească existența unor interacțiuni între aceste două medicamente la nivelul sistemului nervos central. În acest scop, 25 de șobolani femele SpragueDawley au fost împărțiţi în 5 loturi. Grupul I a primit soluție salină subcutanat $0,1 \mathrm{~mL} / 100 \mathrm{gc}$. Grupul II a primit intraperitoneal propilenglicol $1 \mathrm{~mL} / 100 \mathrm{gc}$. Grupul III a primit subcutanat $0,2 \mathrm{mg} / \mathrm{kgc}$ ivermectină. La două ore după administrare, s-au efectuat teste neuro-farmacologice. De asemenea, Grupul IV a primit $20 \mathrm{mg} / \mathrm{kgc}$ etomidat intraperitoneal. Grupul V a primit subcutanat $0,2 \mathrm{mg} / \mathrm{kgc}$ ivermectină și la 2 ore după administrarea ivermectinei, $20 \mathrm{mg} / \mathrm{kgc}$ etomidat a fost administrat intraperitoneal. În aceste două grupuri, anestezia a fost monitorizată și durata somnului a fost calculată pe baza reflexelor rectale. O dată ce animalele s-au trezit, s-au efectuat testele neurofarmacologice. Ivermectina care a fost administrată cu două ore înainte de anestezia cu etomidat a prelungit durata somnului. De asemenea, ivermectina a influenţat mobilitatea și a scăzut coordonarea motorie.

Keywords: ivermectin, etomidate, anaesthesia duration

\section{Introduction}

A drug interaction is a situation in which a substance (usually another drug) affects the activity of a drug when both are administered together. Drug-drug interactions may generate beneficial or harmful outcomes. Drug interaction is one of the common but overlooked problems in medicine. In the clinic, dangerous interactions such as decreased side effects of a drug or even death can be seen when different medications are used together in the treatment of diseases [31, 34]. Therefore, knowing how drug-drug interactions occur and how to manage them is an important part of clinical practice. Ivermectin is an effective antiparasitic drug widely used in veterinary medicine and human medicine in recent years due to its wide spectrum, low toxicity and ease of administration. It is a macrocyclic lactone and semisynthetic derivative of avermectin which is produced by Streptomyces avermitilis. It has potent activity against several parasites and arthropods [26]. It is an agonist for the inhibitory neurotransmitter gamma-aminobutyric acid $(\mathrm{GABA})$ receptors $\left(\mathrm{GABA}_{\mathrm{A}}\right)$ $[2,3] . \mathrm{GABA}_{\mathrm{A}}$ receptors are the major inhibitory neurotransmitter receptors in the brain and are therapeutic targets for many indications including sedation, anaesthesia and anxiolysis. The drug acts by binding GABA-gated chloride (the ion channel receptors, more specific the ion channel receptors specific for chloride) and invertebrate-specific glutamate-gated anion channels 
in peripheral neuromuscular synapses and suppressing nerve impulse conduction [36].

Etomidate is an intravenous general anaesthetic of carboxylated imidazole used in anaesthetic induction and short-term anaesthesia techniques [1,9]. Although, etomidate is widely used in human medicine, it has recently entered the field of veterinary medicine [30]. Since it is a lipophilic and weak base character, when given intravenously, it reaches the highest value in the brain in less than $1 \mathrm{~min}$. [24]. Etomidate interacts with $\mathrm{GABA}_{\mathrm{A}}$ receptors and produces an anaesthetic effect through the $\mathrm{GABA}_{\mathrm{A}}$ receptor/chloride channel complex by inducing a neuron hyperpolarization followed by a general central nervous system depression $[41,45]$.

The mechanisms of action of etomidate and ivermectin used in this study are related to GABA-sensitive chlorine channels. In mammals, however, GABA-ergic receptors are found only in brain. Except for collie dogs, the blood-brain barrier is not permeable to ivermectin. However, certain special conditions such as meningitis and anaesthesia can increase bloodbrain barrier permeability [37, 40].

It is quite difficult to determine the interactions between new drugs during clinical trials before these drugs are introduced to the market. Therefore, it should be kept in mind that the side effects that occur during the administration of newly introduced medications may be related not only to the disease but also to the interaction of the patient with another medication taken at the same time [18].

İvermectin continues to exist in the blood and other tissues for a long time as a result of routine application in some animals in veterinary medicine. In general, the waiting period before slaughter is reported as 28 days for poultry and mammals [46]. In animals where antiparasitic medication is applied, if other medicines are used for treatment before the legal purification period is completed, the risk of interaction between the drugs used and the antiparasitic drugs in the blood and tissues is raised. So, in this study, it was aimed to determine the effect of ivermectin on the duration of anaesthesia performed with etomidate and to find out if there is any interaction between these two drugs at the central nervous system level.

\section{Materials and Methods}

\section{Experimental Animals}

In this study, 25 Sprague-Dawley female rats with an average weight of 150 - 250 grams, with 5 rats in each group, were used. The reason we chose a female rat for our study is that female animals always performed better than males on rotarod tests of motor outcome [25]. Experimental animals were obtained from Van Yüzüncü Y1l University Experimental Animal Unit, Turkey. After the necessary permission was received (number: 2016/04 dated 05.05.2016) from Van YYU
Animal Experiments Local Ethics Committee, animals from Van YYU Experimental Medicine Research and Application Centre were obtained. Rats were housed in rooms with 12 hours light - 12 hours dark lighting up, automatically adjusted temperature $\left(22 \pm 2^{\circ} \mathrm{C}\right)$ and humidity (45 - 50\%) and they were fed with city water supply and standard pellet diet, food and water intake were made free. Food intake was stopped 4 hours before the experiment. Asepsis and antisepsis rules were applied in all the applications. After the experiment, all rats were euthanized under anaesthesia with ketamine $(90 \mathrm{mg} / \mathrm{kg} \mathrm{bw}) / x y l a z i n e ~(10 \mathrm{mg} / \mathrm{kg} \mathrm{bw})$.

Test Procedure

The animals used in this study were divided into the following groups.

Group I: in this group, neuropharmacological tests (open field test and rotarod test) were performed two hours after the rats were given saline $0.1 \mathrm{~g} / 100 \mathrm{~g}$ bw dose subcutaneously.

Group II: the same tests were performed on this group 2 hours after the administration of $1 \mathrm{~mL} / 100 \mathrm{~g} \mathrm{bw}$ of propylene glycol (because ivermectin is formulated in propylene glycol formal (60:40)) with intraperitoneal injection.

Group III: the same tests were performed on the animals in this group 2 hours after the administration of $0.2 \mathrm{mg} / \mathrm{kg}$ bw $(0.1 \mathrm{~mL} / 100 \mathrm{~g} \mathrm{bw})$ ivermectin (İvomec $^{\circledR}$, Merial Saude Animal LTDA, Brazil) subcutaneously. Ivermectin dose was determined for rat according to ESCCAP [12].

Group IV: etomidate (Hypnomidate ${ }^{\circledR}$, Janssen Pharm., Belgium) at a dose of $20 \mathrm{mg} / \mathrm{kg}$ bw ( $1 \mathrm{~mL} / 100 \mathrm{~g} \mathrm{bw})$ was administered to this group with intraperitoneal injection. Anaesthesia was monitored and sleep durations were calculated based on righting reflexes. After the animals were fully awake, neuropharmacological tests were performed.

Group V: in this group, 2 hours after the administration of ivermectin at a dose of $0.2 \mathrm{mg} / \mathrm{kg}$ bw subcutaneously, etomidate was performed at a dose of $20 \mathrm{mg} / \mathrm{kg}$ bw with intraperitoneal injection. Anaesthesia was monitored and sleep durations were calculated based on righting reflexes. After the animals were fully awake, neuropharmacological tests were performed.

Neuropharmacological tests

The rotarod (Mayer, RR0711 model, Turkey) was used for determining the motor incoordination and Animal Locomotor Activity Meter (May ACT model 508, Turkey) was used for open field test.

\section{The rotarod test}

One of the most widely used tests for determining motor incoordination is the rotarod test. This device was first used by Dunham and Miya [10] to test neurological damage in mice and rats. Today, rotarod is still widely used. Since the Rotarod test aims to assess the sensorimotor coordination of the animals, it determines the damage in the brain and the effects of some substances on motor function. Motor 
coordination consists of complex behaviours such as balance, muscle strength, gait, and sensory competence. The loss of motor coordination is one of the most characteristic features of many neurological disorders and the easiest observable effects of drug toxicity [23]. Rotarod apparatus consisted of a bar with a diameter of $5.6 \mathrm{~cm}$, subdivided into five compartments by a disc $19 \mathrm{~cm}$ in diameter. The motor coordination was assessed on the basis of the endurance time of the animals on the rotating rod. The day before the test, the animals were trained twice. On the day of the test only the rats able to stay balanced on the rotating rod between 60 and $120 \mathrm{sec}$ (cut-of time) were selected. Rats were placed on a Rotarod apparatus at a fixed speed $(20 \mathrm{rpm})$ on the day of the experiment after the administration of the drugs. The fall-off latency (time spent until the rat fell off from the rotarod) was recorded. The maximum latency time was set at 300 sec. Three measurements were performed with an interval of 15 minutes.

Open field test

The open field test is used to assess locomotor activity and to measure normal anxiety indirectly [22, 33]. First, in 1936, the circle-based one was described by Hall et al. [14] to test the emotional state of animals. Later, Soubrie [39] developed a square shape. Today, it is one of the most popular tests used in animal neurophysiology. The studies conducted to date have revealed that mice/rats tend to escape when they enter a new area. At the beginning of the experiment, they typically begin to explore the environment along the edge of the wall and avoid going out into the open space. This is because rodents do not feel secure in open and wide environments. During this time, movements of the animal in the horizontal plane (from one tile to another), movements of the animal in the vertical plane (rising on their hind limbs), and the number of defecations are determined. The locomotor activity is directly proportional to the number of passing lines while the exploration of the environment is directly proportional to the number of rising on the hind limbs. The number of defecation is also an indicator of autonomic functions [33]. An animal which is taken outside the environment where it is accustomed to live will probably avoid moving towards the centre of the field and will move less. The purpose of the evaluation of the number of defecations in the open field test is to determine the level of stress in experimental animals. A number of studies have shown that stressful animals are less able to enter the central compartment and have more defecations [11]. The open field consisted of $72 \mathrm{~cm} \times$ $72 \mathrm{~cm}$ Plexiglas square with $36 \mathrm{~cm}$ walls. For analysis, the chamber was divided into sixteen $18 \mathrm{~cm} \times 18 \mathrm{~cm}$ squares. A central square was withdrawn in middle of the open field with red line for counting the crossings in case of high locomotor activity. Each rat was placed in the centre of the open field area and allowed to explore it for $5 \mathrm{~min}$. During the 5 min test session, the variables of locomotor activity (number of black line crossings and central square entries), basic movements, fine movements (such as head-twitching and grooming), and time spent in periphery and central zones were recorded. Open field area was cleaned with $70 \%$ ethanol solution and let dry after testing each rat.

\section{Statistical calculations}

All the data were expressed as mean \pm SEM. All analysis was determined at significance levels of $p<$ 0.05 . The calculation and comparison of the results were performed with the SPSS ${ }^{\circledR}$ version 13 statistical package program. The groups were compared using One-way ANOVA followed by Tukey's multiple comparison test as post hoc test.

\section{Results and Discussion}

The results obtained from the two anesthetized groups are given in Table I. The mean duration of anaesthesia was measured as 94.8 minutes in the etomidate group and 156.4 minutes in the ivermectin group with etomidate. The 61.6 minutes difference between the periods of anaesthesia was statistically significant $(\mathrm{p}<0.05)$

Table I

Anaesthesia (sleep) duration

\begin{tabular}{|l|c|c|}
\hline \multicolumn{1}{|c|}{ Groups } & N & Anaesthesia time (minutes) \\
\hline Group IV & 5 & $94.8 \pm 4.17$ \\
\hline Group V & 5 & $156.4 \pm 20.74 *$ \\
\hline
\end{tabular}

*indicates the difference with other group, $\mathrm{p}<0.05$

Spontaneous locomotor movement test and the number of defecations are given in Table II. A very significant difference was observed in fast movements and indirectly total movement activities in the Groups IV and $\mathrm{V}$ and a decrease in activity was determined due to anaesthesia in these groups. In group III, there was an increase in fast, slow movement and total movement activities. But this increase isn't statistically significant. There was no difference between the groups in terms of the number of defecations.

The results of rotarod test performed to determine the disturbances in motor coordination capacity are shown in Figure 1. İvermectin caused a decrease in motor coordination both Group III and Group V. Although the decrease in Group III is not statistically significant, the incoordination of Group $\mathrm{V}$ was found to be significant when compared with other groups. Moreover, time-related improvements were observed. 
Table II

Spontaneous locomotor movement test results

\begin{tabular}{|l|c|c|c|c|c|}
\hline \multirow{2}{*}{ Groups } & \multirow{2}{*}{$\mathbf{N}$} & \multicolumn{3}{|c|}{ Motion } & \multirow{2}{*}{ Defecation } \\
\cline { 3 - 5 } & & Fast & Slow & Total & \\
\hline Group I & 5 & $3989.2 \pm 684.25^{a b}$ & $574.2 \pm 92.22^{a b}$ & $4563.4 \pm 759.8^{a b}$ & $4.4 \pm 0.75$ \\
\hline Group II & 5 & $3793.8 \pm 911.97^{b}$ & $470.4 \pm 107.03^{a}$ & $4264.2 \pm 997.91^{b}$ & $1.8 \pm 0.8$ \\
\hline Group III & 5 & $5555.0 \pm 353.48^{a}$ & $810.4 \pm 94.32^{a}$ & $6365.4 \pm 397.31^{a}$ & $1.4 \pm 1.17$ \\
\hline Group IV & 5 & $901.8 \pm 216.18^{c}$ & $343.0 \pm 98.58^{b}$ & $1244.8 \pm 293.16^{c}$ & $2.8 \pm 0.86$ \\
\hline Group V & 5 & $1073.6 \pm 243.02^{c}$ & $309.6 \pm 72.7^{b}$ & $1381.2 \pm 288.44^{c}$ & $2.4 \pm 1.17$ \\
\hline
\end{tabular}

$\mathrm{a}, \mathrm{b}, \mathrm{c}$ indicates the difference between groups, $\mathrm{p}<0.05$

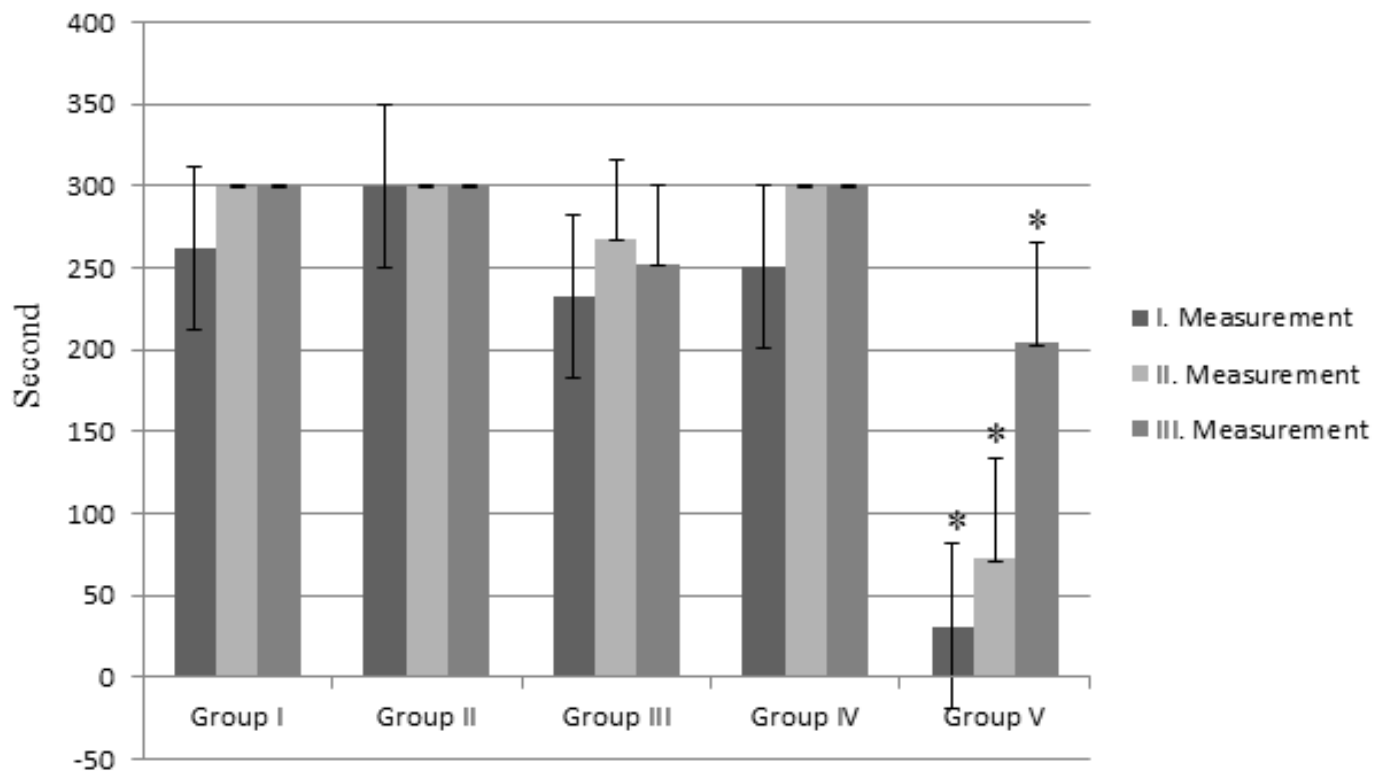

Figure 1.

Rotarod test results $(*-$ indicates the difference with other groups, $\mathrm{p}<0.05$ )

Anaesthesia is a procedure that must be performed very carefully and also the doses of anaesthetic drugs must be calculated very well. A small overdose may result in death. Anaesthetic drugs are generally dangerous because their therapeutic indices are low. Depending on the dose, the transition from surgical anaesthesia to medullary paralysis can be easy. The view that the effect of anaesthetics is shaped in biomembrane and that the anaesthetic effect is caused by swelling, volume change and fluidization in excitable membranes is still valid today [13].

In this study, the mean duration of anaesthesia in Group V was significantly ( $p<0.05$ ) increased according to Group IV (Table I). In the study where mice received etomidate at a dose of $7.5 \mathrm{mg} / \mathrm{kg} \mathrm{bw}$ [21], the duration of anaesthesia was found to be $11.6 \mathrm{~min}$ in wild-type mice and $4 \mathrm{~min}$ in mutants. In this study, shortness of anaesthesia period can be attributed to the fact that the animal species is different and the dose is very low. Trailovic et al. [43] found that sub-depressant doses of ivermectin significantly prolonged the duration of thiopental anaesthesia. Anaesthesia duration with $35 \mathrm{mg} / \mathrm{kg}$ bw thiopental was $34.13 \pm 3.24 \mathrm{~min}$., when $7.5 \mathrm{mg} / \mathrm{kg}$ bw ivermectin was administered, anaesthesia duration resulted in $232.13 \pm 9.53 \mathrm{~min}$. Ceylan and Y1lmaz [5] reported that the mean duration of pentobarbital sodium anaesthesia in rats was $27.2 \pm 3.47 \mathrm{~min}$; in the case of administered ivermectin 30 minutes before the anaesthesia group, this duration was found to be $59 \pm 8.4 \mathrm{~min}$; in the case of administered ivermectin 2 hours before anaesthesia group, this duration was found to be $68.33 \pm 9.74 \mathrm{~min}$, and in the case of administered ivermectin 24 hours before anaesthesia group, it was found to be $29 \pm 3.47 \mathrm{~min}$. Also, Ceylan et al. [4] determined that the duration of anaesthesia with a volatile anaesthetics halothane $(2.86 \mathrm{~min})$ in mice was $7.16 \mathrm{~min}$ when ivermectin was administered, and the duration of the ether anaesthesia (3.4 min) was 7.41 minutes when ivermectin was administered. The findings obtained in this study are compatible with those of other studies. In this study, it is thought that GABA-mediated inhibition might be the reason for ivermectin treatment to increase sleep time in etomidate anaesthesia.

A very significant difference was observed in fast movements and indirectly total movement activities in the Groups IV and V, and a decrease in activity was determined due to anaesthesia in these groups at spontaneous locomotor movement test (Table II). 
In another study [6], etomidate (4 and $10 \mathrm{mg} / \mathrm{kg} \mathrm{bw}$ ) caused a similar reduction in spontaneous movement at $30 \mathrm{~min}$ in the wild-type (WT) and $\alpha 5$ null mutant mice. Also, Diaz-Gil et al. [8] determined that doses of 2 and $4 \mathrm{mg} / \mathrm{kg}$ bw etomidate caused hypo-locomotion in the open field test in rats. Wang et al. [47] reported that etomidate caused a slow recovery of spontaneous activity in open field test. In another study [35], it was observed that low doses of etomidate $(0.3-7.5 \mathrm{mg} / \mathrm{kg}$ bw) decreased spontaneous locomotor activity in wild-type mice. But, at higher doses of etomidate (10 and $12.5 \mathrm{mg} / \mathrm{kg}$ bw) showed low spontan locomotor activity in both wild-type and $\beta 2$ N265S mice. These results are in correlation with our study. In this study, the animals which were administered treatment dose of ivermectin were more active than the other groups during the spontaneous locomotor movement test. Therefore, ivermectin caused increased movement rather than CNS depression.

Parisi et al. [29] administered $0.2 \mathrm{mg} / \mathrm{kg}$ bw and 1 $\mathrm{mg} / \mathrm{kg}$ bw ivermectin to rats, and they determined $0.2 \mathrm{mg} / \mathrm{kg}$ bw dose of ivermectin did not change locomotor activity, but $1 \mathrm{mg} / \mathrm{kg}$ bw dose increased ivermectin locomotor activity in the open field test performed 48 hours after this application. The mechanism of the effect of ivermectin on open field testing has not yet been established. It is known that the antihelminthic effect of ivermectin occurs with a systemic release of GABA, although it has been reported that ivermectin cannot cross the blood brain barrier and thus cannot reach GABAergic synapses [32]. It has also been shown that a small concentration of ivermectin can cross the sufficient blood brain barrier for the CNS movements. Lipophilic drugs that alter cell membranes (like anaesthetics) may also alter the blood-brain barrier [29]. Furthermore, recent studies show that ivermectin can function as a positive allosteric modulator of nicotinic Ach receptors in the mammalian brain [19]. Another possible pharmacological effect of ivermectin is thought to be that it affects the peripheral nervous system or a peripheral organ and can transmit sensory information that will affect the behavioural parameters to the brain [7]. Although, there was no statistical difference between the groups, the number of defecation decreased especially in the group II and group III (Table II), because ivermectin and propylene glycol may have caused damage to autonomic functions and consequently have reduced the response to stress as defecation.

Rotarod performance test is a method used to test whether motor coordination, balance, physical condition and motor functioning in rodents are disturbed [16]. After the application of the anaesthetic agent has ended, the response to the verbal stimulus takes less time to recover than cognitive and motor coordination. This is important since motor and cognitive coordination show that the patient undertakes his own functions. In this study, regarding the rotarod performance in
Group IV (etomidate), there was no difference with other groups. But, Ozcan and Barışkaner [27] determined that $5 \mathrm{mg} / \mathrm{kg}$ bw and $10 \mathrm{mg} / \mathrm{kg}$ bw doses of etomidate decreased motor coordination in male Sprague-Dawley albino rats at $15^{\text {th }}$ and $30^{\text {th }}$ minutes in the rotarod test. Another anaesthetic, propofol, did not affect motor activity in rats [28] and in mice [20]. Also, in different studies, it was observed that rotarod performances did not change in mice and rats anesthetized with isoflurane [15, 38, 48]. Ivermectin decreased rotarod performance in Group III (ivermectin) and especially in Group V (etomidate + ivermectin) (Figure 1). So, it can be said that there is an interaction between etomidate and ivermectin in the rotarod test. Unlike our results, Davis et al. [7], administered ivermectin to mice with drinking water at 0.008 $\mathrm{mg} / \mathrm{mL}$ for 8 weeks and they determined that ivermectin does not affect rotarod performance and therefore has no effect on motor activity. Janko and Geyer [17] administered ivermectin orally in increasing doses to mice and found that the therapeutic dose of $0.2 \mathrm{mg} / \mathrm{kg}$ bw was not affected by the rotarod performance of animals. In addition, there are different studies that determine GABA agonists reduce motor activity [42]. In a study, Trailovic et al. [43] found that sub-depressant doses (14 - 41\% of $\mathrm{LD}_{50}$ ) of ivermectin decreased motor coordination. Trailovic et al. [44] applied ivermectin to the isolated rat diaphragm $(1.25,2.5$, $3.75,5.0,6.25$ and $7.5 \mathrm{mg} / \mathrm{kg} \mathrm{bw}$ ) and they reported that motor activity was impaired in increasing doses. Our findings are compatible with their results.

\section{Conclusions}

As a general conclusion, ivermectin that was administered two hours before the etomidate anaesthesia prolonged etomidate sleeping duration strongly. Also, ivermectin increased motion (Table II) and decreased motor coordination (Figure 1), in association with etomidate it potentiates CNS depression (with prolonged sleep duration and decreased motor coordination).

Our results show that ivermectin changes the duration of anaesthesia and behavioural parameters. So, if anaesthesia is to be performed on animals that are administered ivermectin, the dose of the anaesthetic must be well adjusted, otherwise there is a risk of negative consequences.

\section{Acknowledgement}

The authors would like to thank the Van Yüzüncü Y1l University Scientific Research Projects Department for their financial support for the 2009-VF-B040 research project. 
Conflict of interest

The authors declare no conflict of interest.

\section{References}

1. Barash PG, Cullen BF, Stoelting RK, Clinical Anesthesia. Publication of Lippincott Williams \& Wilkins, Philadelphia, 2006; 344-345.

2. Barragy TB, A review of pharmacology and a clinical uses of ivermectin. Can Vet J., 1987; 28(8): 512-517.

3. Ceylan S, Yilmaz O, Recent developments about avermectin. J Uludağ Uni Vet Med., 1987; 5: 283-289.

4. Ceylan S, Yılmaz O, Sağmanlıgil H, Effects of ivermectin and fenvalerate on general anesthesia with halothane and ether. J Uludağ Uni Vet Med., 1991; 10: 105-111.

5. Ceylan S, Yilmaz O, Effect of ivermectin on general anesthesia induced by pentobarbital sodium. J Uludağ Uni Vet Med., 1993; 12: 68-72.

6. Cheng VY, Martin LJ, Elliott EM, Kim JH, Mount HT, Taverna FA, Roder JC, Macdonald JF, Bhambri A, Collinson N, Wafford KA, Orser BA, a5GABAA receptors mediate the amnestic but not sedative-hypnotic effects of the general anesthetic etomidate. J Neurosci., 2006; 26(14): 3713-3720.

7. Davis JA, Paylor R, McDonald MP, Libbey M, Ligler A, Bryant K, Crawley JN, Behavioral effects of ivermectin in mice. Lab Anim Sci., 1999; 49(3): 288-296.

8. Diaz-Gil D, Mueller N, Moreno-Duarte I, Lin H, Ayata C, Cusin C, Cotten JF, Eikermann M, Etomidate and Ketamine: Residual Motor and Adrenal Dysfunction that Persist beyond Recovery from Loss of Righting Reflex in Rats. Pharmaceuticals, 2015; 8(1): 21-37.

9. Doenicke A, Etomidate, a new intravenous hypnotic. Acta Anaesthesiol Belg., 1974; 25: 307-315.

10. Dunham NW, Miya TS, A note on a simple apparatus for detecting neurological deficit in rats and mice. $J$ Am Pharm Assoc., 1957; 46: 208-209.

11. Erdoğan F, Gölgeli A, Arman F, The effects of pentylenetetrazole-induced status epilepticus on behavior, emotional memory and learning in rats. Epilepsy \& Behavior, 2004; 5: 388-393.

12. ESCCAP, ESCCAP Guideline 07 First Edition - July 2017. www.esccap.org/uploads/docs/t5h0njo2_0576_ ESCCAP_Guideline_GL7_v11_1p.pdf.

13. Franks NP, Lieb WR, Molecular mechanisms of general anaesthesia. Nature, 1982; 300: 487-493.

14. Hall CS, Emotional behavior in the rat. III. The relationship between emotionality and ambulatory activity. J Comp Physiol Psychol., 1936; 22: 345-352.

15. Hohlbaum K, Bert B, Dietze S, Palme R, Fink H, Thone-Reineke C, Severity classification of repeated isoflurane anesthesia in C57BL/6JRj mice assessing the degree of distress. Plos One, 2017; 12(6): e0179588: $1-21$.

16. Iancu R, Mohapel P, Brundin P, Paul G, Behavioral characterization of a unilateral 6-OHDA-lesion model of Parkinson"s disease in mice. Behav Brain Res., 2005; 162(1): 1-10.

17. Janko C, Geyer J, Moxidectin has a lower neurotoxic potential but comparable brain penetration in $\mathrm{P}$ glycoprotein-deficient CF-1 mice compared to ivermectin. J Vet Pharmacol Ther., 2013; 36(3): 275-284.
18. Kayaalp O, Medical pharmacology in terms of rational therapy, Publication of Pelikan bookstore, Ankara, 2012; 104.

19. Krause RM, Buisson B, Bertrand S, Corringer PJ, Galzi JL, Changeuz JP, Bertrand D, Ivermectin: a positive allosteric effector of the $\alpha 7$ neuronal nicotinic acetylcholine receptor. Mol Pharmacol., 1998; 53(2): 283-294.

20. Kurt M, Bilge S, Kukula O, Celik S, Kesim Y, Anxiolytic-like profile of propofol, a general anesthetic, in the plus-maze test in mice. Pol J Pharmacol., 2003; 55: 973-977.

21. Liao M, Sonner JM, Husain SS, Miller KW, Jurd R, Rudolph U, Eger E, R(+) Etomidate and photoactivable $\mathrm{R}(+)$ azietomidate have comparable anesthetic activity in wild-type mice and comparably decreased activity in mice with a $\mathrm{N} 265 \mathrm{M}$ point mutation in the gammaaminobutyric acid receptor $\beta 3$ subunit. Anesth Analg., 2005; 101: 131-135.

22. Lieben CKJ, Oorsouw K, Deutz NEP, Blokland A, Acut tryptophan depletion induced by a gelatin-based mixture impairs object memory but not affective behavior and spatial learning in the rat. Behav Brain Res., 2004; 151: 53-64.

23. Mercan U, The protective effect of antioxidants on potential chronic toxic effects of repellents in infants. Yüzüncü Y1l Univercity, Health Science Institute, Pharmacology and Toxicology Department, Doctorate Thesis, Van, 2007; 108.

24. Meyer RE, Fish RE, Pharmacology of injectable anesthetics, sedatives and tranquilizers. RE Fish, MJ Brown, PJ Danneman, AZ Karas (Eds.) Anesthesia and Analgesia in Laboratory Animals, $2^{\text {nd }}$ ed, Academic Press, 2008; 37-38.

25. O'Connor CA, Cernak I, Vink R, Interaction between Anesthesia, Gender, and Functional Outcome Task following Diffuse Traumatic Brain Injury in Rats. $J$ Neurotrauma, 2004; 20(6): 533-541.

26. Omura S, Crump A, The life and times of ivermectin a success story. Nat Rev Microbiol., 2004; 2: 984-989.

27. Ozcan B, Barışkaner H, A comparative analyses effects of dexmedetomidine and etomidate on motor coordination and analgesia in rats. Der Pharma Chem., 2015, 7(12): 201-204.

28. Pain L, Angst MJ, LeGourrier L, Oberling P, Effect of a nonsedative dose of propofol on memory for aversively loaded information in rats. Anesthesiology, 2002; 97: 447-453.

29. Parisi DP, Santos SAR, Cabral D, Queiroz-Hazarbassanov N, Florio JC, Bernardi MM, Kirsten TB, Therapeutical doses of ivermectin and its association with stress disrupt motor and social behaviors of juvenile rats and serotonergic and dopaminergic Systems. Res Vet Sci., 2019; 124: 149-157.

30. Perk C, Güzel Ö, Gülanber EG, Etomidate/Alfentanil anaesthesia in dogs and its effects on pulse oxymeter, electrocardiography and hematological parameters. Turk J Vet Anim Sci., 2002; 26: 1021-1024.

31. Pirmohamed M, James S, Meakin S, Green C, Scott AK, Walley TJ, Farrar K, Park BK, Breckenridge AM, Adverse drug reactions as cause of admission to hospital: prospective analysis of 18820 patients. BMJ., 2004; 329: 15-19. 
32. Poul JM, Effects of perinatal ivermectin exposure on behavioral development of rats. Neurotoxicol Teratol., 1988; 10: 267-272.

33. Prut I, Belzung C, The open field as a paradigm to measure the effects of drugs on anxiety-like behaviors: a review. Euro J Pharmacol., 2003; 463: 3-33.

34. Riaz MK, Potential drug-drug interactions and strategies for their detection and prevention. Farmacia, 2019; 67(4): 572-579.

35. Reynolds DS, Rosahl TW, Cirone J, O'Meara GF, Haythornthwaite A, Newman RJ, Myers J, Sur C, Howell O, Rutter AR, Atack J, Macaulay AJ, Hadingham KL, Hutson PH, Belelli D, Lambert JJ, Dawson GR, McKernan R, Whiting PJ, Wafford KA, Sedation and anesthesia mediated by distinct GABAA receptor isoforms. J Neurosci., 2003; 23(24): 8608-8617.

36. Ricart Arbona RJ, Lipman NS, Riedel ER, Wolf FR, Treatment and eradication of murine fur mites: I. Toxicologic evaluation of ivermectin-compounded feed. J Am Assoc Lab Anim Sci., 2010; 49: 564-570.

37. Saija A, Pirinci P, De Pasquale R, Costa G, Modification of the permeability of the blood-brain barrier and local cerebral metabolism in pentobarbital and ketamineanaesthetized rats. Neuropharmacol., 1989; 28: $997-$ 1002.

38. Sanders RD, Xu J, Shu Y, Fidalgo A, Ma D, Maze M, General anesthetics induce apoptotic neurodegeneration in the neonatal rat spinal cord. Anesth Analg., 2008; 106(6): 1708-1711.

39. Soubrie P, Open fieldchez le rat: interrelations entrelocomotion exploration et emotivite. J Pharmacol., 1971; 2: 457.

40. Stewart PA, Hayakawa EM, Carlen PL, Ethanol and pentobarbital in combination increase blood-brain barrier permeability to horseradish peroxidase. Brain Res., 1988; 443: 12-20.
41. Tomlin SL, Jenkins A, Lieb WR, Franks NP, Stereoselective effects of etomidate optical isomers on gammaaminobutyric acid type A receptors and animals. Anesthesiology, 1998; 88: 708-717.

42. Topkara B, Yananli HR, Sakallı E, Demirkapu MJ, Effects of Injection of Gamma-Aminobutyric Acid agonists into the nucleus accumbens on naloxoneinduced morphine withdrawal. Pharmacology, 2017; 100: 131-138.

43. Trailovic SM, Jezdimirovic MB, Djurdjevic D, Influence of ivermectin on thiopentone sleeping-time and motor coordination in rats. B-63 (0298) Abstracts from the $9^{\text {th }}$ International Congress of the European Association of Veterinary Pharmacology and Toxicology, Lisbon, 2003; 186.

44. Trailovic SM, Ivanovic SR, Varagi'c VM, Ivermectin effects on motor coordination and contractions of isolated rat diaphragm. Res Vet Sci., 2011; 91: 426-433.

45. Uchida I, Kamatchi G, Burt D, Yang J, Etomidate potentiation of GABA-A receptor gated current depends on the subunit composition. Neurosci Lett., 1995; 185: 203-206.

46. Ustüner $\mathrm{O}$, Antiparasitic drugs used in veterinary medicine. Publication of Istanbul University Faculty of Veterinary Medicine, Istanbul, 2016; 33-34.

47. Wang Bin MD, Yang Jun PhD, Chen Jun MS, Kang Yi BS, Yang Ling-Hui PhD, Liu Jin MD, Zhang Wen-Sheng MD, An Etomidate Analogue With Less Adrenocortical Suppression, Stable Hemodynamics, and Improved Behavioral Recovery in Rats. Anesth Analg., 2017; 125(2): 442-450.

48. Yonezaki K, Uchimoto K, Miyazaki T, Asakura A, Kobayashi A, Takase K, Goto T, Postanesthetic effects of isoflurane on behavioral phenotypes of adult male C57BL/6J mice. PLoS One, 2015; 10(3): 1-23. 